\title{
Intercellular Interactions, Position, and Polarity in Establishing Blastocyst Cell Lineages and Embryonic Axes
}

\author{
Robert O. Stephenson ${ }^{1,2}$, Janet Rossant ${ }^{1,2}$, and Patrick P.L. Tam ${ }^{3}$ \\ ${ }^{1}$ Program in Developmental and Stem Cell Biology, The Hospital for Sick Children Research Institute, Toronto, \\ Ontario M5G 1X8, Canada \\ ${ }^{2}$ Department of Molecular Genetics, University of Toronto, Toronto, Ontario M5S 1A1, Canada \\ ${ }^{3}$ Embryology Unit, Children's Medical Research Institute and Discipline of Medicine, Sydney Medical School, \\ University of Sydney, Westmead, New South Wales 2145, Australia \\ Correspondence: janet.rossant@sickkids.ca
}

\section{SUMMARY}

The formation of the three lineages of the mouse blastocyst provides a powerful model system to study interactions among cell behavior, cell signaling, and lineage development. Hippo signaling differences between the inner and outer cells of the early cleavage stages, combined with establishment of a stably polarized outer epithelium, lead to the establishment of the inner cell mass and the trophectoderm, whereas FGF signaling differences among the individual cells of the ICM lead to gradual separation and segregation of the epiblast and primitive endoderm lineages. Events in the late blastocyst lead to the formation of a special subset of cells from the primitive endoderm that are key sources for the signals that establish the subsequent body axis. The slow pace of mouse early development, the ability to culture embryos over this time period, the increasing availability of live cell imaging tools, and the ability to modify gene expression at will are providing increasing insights into the cell biology of early cell fate decisions.

\section{Outline}

\section{Introduction}

2 Lineage specification in the blastocyst: Transcriptional network control

3 The relationship between morphogenesis, cell signaling, and lineage allocation in the preimplantation embryo
4 Relationship of cell fates and the architecture of the blastocyst with the patterning of the postimplantation embryo

5 Conclusions and future directions

References

Editors: Patrick P.L. Tam, W. James Nelson, and Janet Rossant

Additional Perspectives on Mammalian Development available at www.cshperspectives.org

Copyright (C 2012 Cold Spring Harbor Laboratory Press; all rights reserved; doi: 10.1101/cshperspect.a008235

Cite this article as Cold Spring Harb Perspect Biol 2012;4:a008235 


\section{INTRODUCTION}

The development of the mammalian blastocyst provides an excellent model system for studying the relationship between cellular morphogenesis and cell fate. During the first $4 \mathrm{~d}$ of development in the mouse, a single-cell zygote undergoes a series of cleavage cell divisions and morphogenetic changes to form a fluid-filled epithelial vesicle enclosing a compact group of cells, the inner cell mass (ICM). By this late blastocyst stage of development, the outer epithelium is committed to form the trophectoderm (TE), which subsequently gives rise to the trophoblast layers of the placenta and the trophoblast giant cells. Within the inner cell mass, there has been a further separation into two cell types, primitive endoderm (PE) and epiblast (EPI). The epiblast cells are the pluripotent cell lineage of the blastocyst, giving rise to all of the primary germ layers of the fetus and its extraembryonic membranes, whereas the primitive endoderm primarily gives rise to the endoderm layer of the extraembryonic yolk sacs. Extensive lineage analysis and experimental studies using chimeric embryos over many years have precisely established the prospective fate of these cell types. Restriction of cell fate takes place over an extended time period of $48 \mathrm{~h}$ from the 8 -cell stage, when all cells are capable of forming all three cell types. By the late blastocyst stage, cells are irreversibly committed to the three distinct lineages. These studies have been extensively reviewed elsewhere and are only summarized here (Fig. 1A).

During preimplantation development, a series of important morphogenetic events occurs that are tightly linked to the lineage events of blastocyst development:

1. The first of these events is compaction of the embryo, in which the embryo surface smoothens because of an increase in intercellular adhesion. Concomitant with compaction, cells of the embryo undergo apical-basal polarization, a process that is characterized by the apical enrichment of actin and clathrin in the cytoplasm and glycoproteins and microvilli on the cell surface (Ducibella et al. 1977; Handyside 1980; Reeve and Ziomek 1981; Pratt et al. 1982; Maro et al. 1985).

2. The next phase of development from 16 to 32 cells involves the development of an outer polarized epithelial monolayer, enclosing a group of apolar cells. The maturation of tight junctions between outer cells at embryonic day 3.5 (E3.5) ( 32-cell stage) enables the generation of a large fluid-filled cavity within the early embryo known as the blastocoel (Fleming and Johnson 1988; Fleming et al. 2000).

3. With blastocoel formation, the embryo transitions into the "blastocyst" phase of development. The eccentric placement of the ICM at one end of the blastocyst demarcates two populations of cells within the TE. The polar TE overlays the ICM, whereas the mural TE encompasses the blastocoel cavity.

4. The final event in blastocyst formation is the segregation of a monolayer of primitive endoderm on the blastocoelic surface of the ICM by E4.5, enclosing the remaining pluripotent epiblast progenitors. By this stage, the embryo is ready to implant in the uterus, and the complex events leading to axis formation and gastrulation begin.

5. Recent studies have revealed the regionalization of a group of cells in the primitive endoderm of the blastocyst and the visceral endoderm (VE) of the postimplantation embryo that give rise to a specialized population of cells endowed with signaling function (Fig. 1B) (Takaoka et al. 2006, 2011; Takaoka and Hamada 2012). These findings highlight the possibility that the positioning of these cells, which act as a source of morphogenetic signals, may endow tissue asymmetry in the blastocyst and consequently heralds the specification of the body axis.

In this article, we review the transcriptional networks for lineage restriction, the molecular pathways underlying cell signaling and cellular morphogenesis in the early embryo, and the growing knowledge of the intimate linkage between the two.

\section{LINEAGE SPECIFICATION IN THE BLASTOCYST: TRANSCRIPTIONAL NETWORK CONTROL}

There has been considerable progress in recent years in identifying the transcription factors (TFs) and their regulatory interactions that are required for maintenance of lineage specification. Here we focus on a few transcription factors that have key roles in the segregation of the blastocyst lineages. Data on a selection of transcription factors that play a role in extraembryonic lineage maintenance are summarized in Table 1. Factors involved in the pluripotent epiblast lineage are summarized in Nichols and Smith (2012).

Consistent with the known gradual restriction of cell fate during preimplantation development, many TFs are broadly expressed during early development and only become restricted to lineage around the time of lineage specification. For example, expression of the transcription factor Oct4 is apparent in all cells from oocyte on, but only becomes restricted to the ICM after E3.5 (Palmieri et al. 1994; Dietrich and Hiiragi 2007). It has been suggested that differences in the kinetics of Oct4 nuclear activity may predict future ICM fate during cleavage stages, 
A

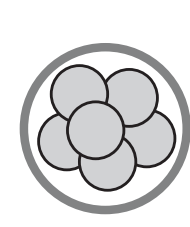

8-cell $\sim \mathrm{E} 2.5$
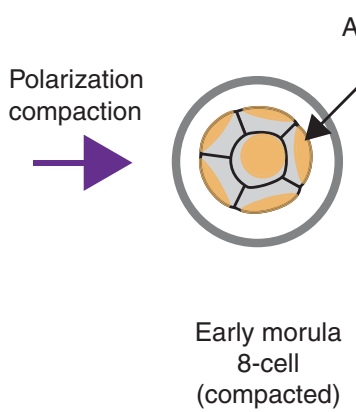

Apical domain

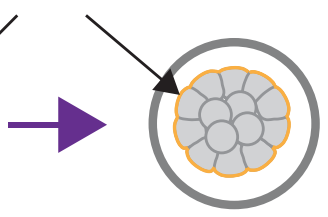

$$
\begin{gathered}
\text { Late morula } \\
\text { 16-32 cell }
\end{gathered}
$$

Polar

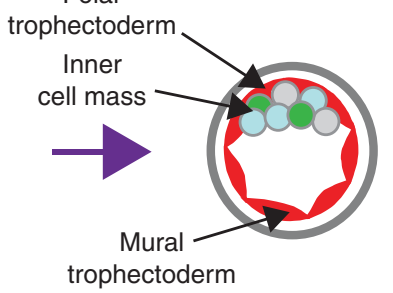

Early blastocyst E3.5

B

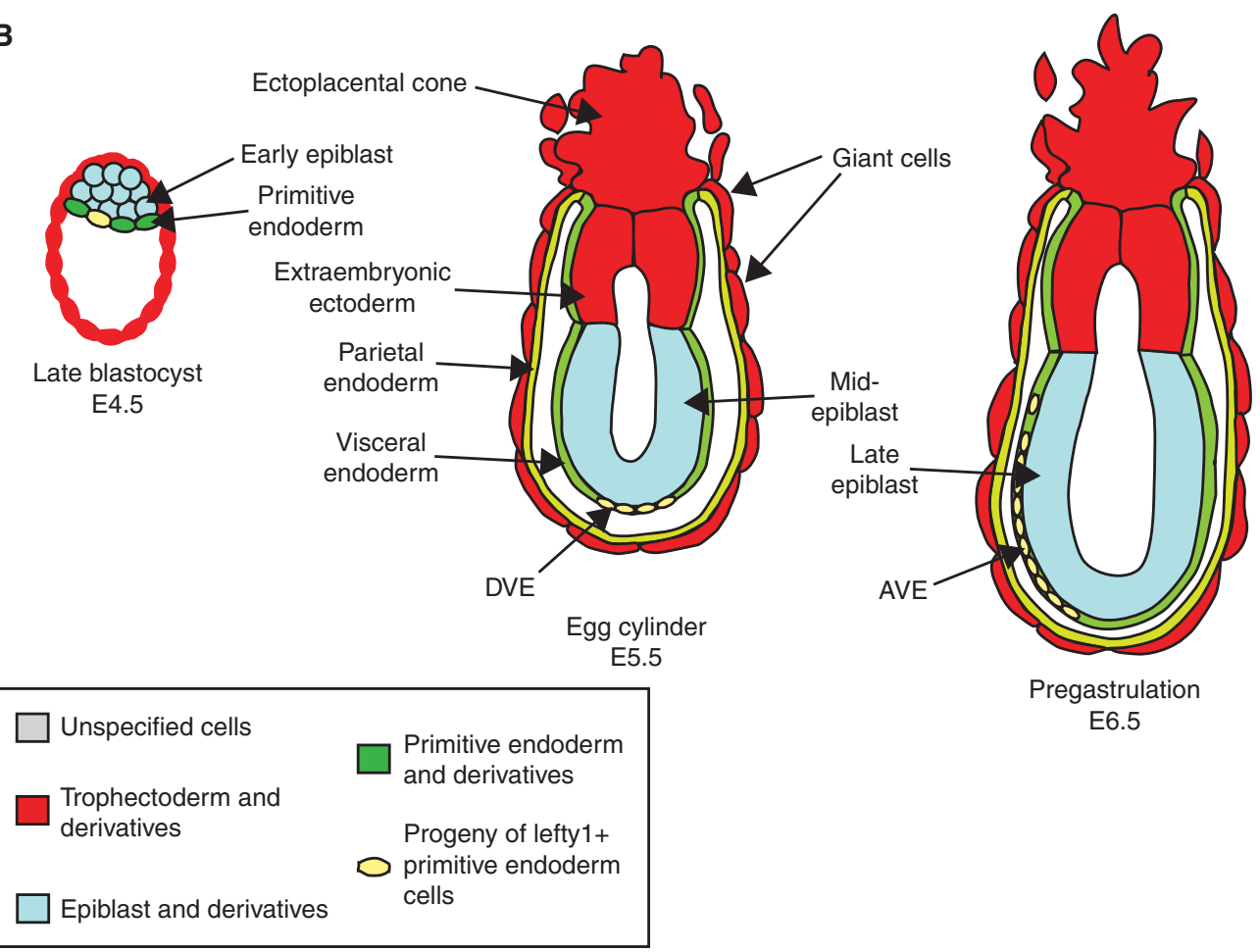

Figure 1. Overview of mouse peri-implantation development. (A) Preimplantation stages. Blastomeres undergo compaction and apicobasal polarization at the 8-cell stage. By embryonic day 3.5 (E3.5), the embryo forms a blastocyst. At E3.5 the trophectoderm (TE) is a single-cell polarized epithelium on the surface of the embryo, while the inner cell mass (ICM) consists of a mass of apolar cells eccentrically located in the blastocyst interior. (B) Early postimplantation stages. By E4.5, the epiblast (EPI) and primitive endoderm (PE) layers have clearly segregated in the ICM, and the embryo is ready to implant in the uterus. After implantation, the TE elaborates into extraembryonic ectoderm, the ectoplacental cone, and trophoblast giant cells, whereas the PE further differentiates into the visceral endoderm (VE), parietal endoderm, and specialized subpopulations of VE: first the distal visceral endoderm (DVE) at E5.5, and subsequently the anterior visceral endoderm (AVE) at E6.5.

although the mechanism of such predisposition is unclear (Plachta et al. 2011). Oct4 is, however, a key player in the generation of ICM versus TE fate. Embryos lacking the Pou5f1 gene that encodes Oct4 generate an ICM that expresses TE markers (Nichols et al. 1998; Ralston et al. 2010). In addition, loss of Oct4 in embryonic stem (ES) cells (an in vitro model of early EPI) leads to differentiation into trophoblast stem (TS) cells (an in vitro model of trophectoderm) (Niwa et al. 2002, 2005). Mutations in other players in the pluripotent TF network in ES cells (e.g., Sox2, Nanog, Klf5) disrupt epiblast formation but do not default to a TE fate (Avilion et al. 2003; Mitsui et al. 2003; Chambers et al. 2007; Ema et al. 2008; Lin et al. 2010).

Among the genes up-regulated when Oct4 is lost in the blastocyst or in ES cells is the caudal homeodomain 
R.O. Stephenson et al.

Table 1. Selected transcription factors implicated in TE and PE differentiation

\begin{tabular}{|c|c|c|c|c|c|}
\hline Name & Initial expression & Localization & $\begin{array}{l}\text { Loss-of-function } \\
\text { phenotype }\end{array}$ & $\begin{array}{l}\text { Gain-of-function } \\
\text { phenotype }\end{array}$ & References \\
\hline \multicolumn{6}{|c|}{ TE-specific transcription factors } \\
\hline $\mathrm{Cdx} 2$ & $\begin{array}{l}\text { Evidence for maternal } \\
\text { mRNA; protein } \\
\text { detected at 8-cell } \\
\text { stage }\end{array}$ & $\begin{array}{l}\text { Restricted to TE at E3.5; } \\
\text { ubiquitous before } \\
\text { 32-cell stage }\end{array}$ & $\begin{array}{l}\text { Zygotic mutant: TE } \\
\text { develops, but dies; } \\
\text { TE expresses ICM } \\
\text { markers; siRNA of } \\
\text { maternal and zygotic } \\
\text { transcripts; variable } \\
\text { results }\end{array}$ & $\begin{array}{l}\text { Expression in ES cells } \\
\text { induces TS cell } \\
\text { differentiation }\end{array}$ & $\begin{array}{l}\text { Niwa et al. 2005; } \\
\text { Strumpf et al. } \\
\text { 2005; Dietrich } \\
\text { and Hiiragi 2007; } \\
\text { Ralston and } \\
\text { Rossant 2008; } \\
\text { Jedrusik et al. } \\
\text { 2010; Wu et al. } \\
2010\end{array}$ \\
\hline Tead4 & $\begin{array}{l}\text { mRNA detectable at } 2 \text { - } \\
\text { to } 4 \text {-cell stage; } \\
\text { protein at } \sim 4 \text {-cell } \\
\text { stage }\end{array}$ & $\begin{array}{l}\text { Ubiquitous throughout } \\
\text { preimplantation }\end{array}$ & $\begin{array}{l}\text { Zygotic mutant: loss of } \\
\text { Cdx2 expression } \\
\text { after 8-cell stage; } \\
\text { ectopic ICM markers } \\
\text { in surface cells; } \\
\text { failure to form } \\
\text { blastocyst }\end{array}$ & $\begin{array}{l}\text { Expression of Tead4 } \\
\text { DNA-binding } \\
\text { domain fused to } \\
\text { VP16 transcriptional } \\
\text { activation domain in } \\
\text { ES cells induces TS } \\
\text { cell differentiation }\end{array}$ & $\begin{array}{l}\text { Yagi et al. 2007; } \\
\text { Nishioka et al. } \\
\text { 2008, } 2009\end{array}$ \\
\hline $\begin{array}{l}\text { Yap1 (Wwtr1 is } \\
\text { similar to Yap) }\end{array}$ & $\begin{array}{l}\text { mRNA and nuclear } \\
\text { protein detectable } \\
\text { from 4-cell stage }\end{array}$ & $\begin{array}{l}\text { Nuclear-localized in } \\
\text { outer cells; } \\
\text { cytoplasmic in inner } \\
\text { cells (Wwtr1 does } \\
\text { not appear to have } \\
\text { cytoplasmic } \\
\text { distribution in inner } \\
\text { cells) }\end{array}$ & $\begin{array}{l}\text { Dominant-negative } \\
\text { Yap expression leads } \\
\text { to reduced Cdx } 2 \\
\text { expression }\end{array}$ & $\begin{array}{l}\text { Overexpression in } \\
\text { inner cells of } \\
\text { blastocyst induces } \\
\mathrm{Cdx} 2 \text { expression }\end{array}$ & Nishioka et al. 2009 \\
\hline Eomes & $\begin{array}{l}\text { Protein undetectable } \\
\text { until blastocyst stage }\end{array}$ & Restricted to TE & $\begin{array}{l}\text { Zygotic mutant: form } \\
\text { TE that expresses } \\
\text { Cdx2, but fail to } \\
\text { implant, and TE fails } \\
\text { to differentiate }\end{array}$ & $\begin{array}{l}\text { Expression in ES cells } \\
\text { induces TS cell } \\
\text { differentiation, but } \\
\text { TS cells require Cdx2 } \\
\text { expression for } \\
\text { maintenance }\end{array}$ & $\begin{array}{l}\text { Niwa et al. 2005; } \\
\text { Strumpf et al. } \\
\text { 2005; Ralston } \\
\text { and Rossant } 2008\end{array}$ \\
\hline Gata3 & $\begin{array}{l}\text { mRNA detected at low } \\
\text { levels at } 1 \text {-cell stage; } \\
\text { protein detected at } \\
\text { late } 8 \text {-cell stage }\end{array}$ & $\begin{array}{l}\text { Restricted to TE at E3.5; } \\
\text { ubiquitous before } \\
\text { this }\end{array}$ & $\begin{array}{l}\text { Zygotic mutants have } \\
\text { postimplantation } \\
\text { phenotype with } \\
\text { placental defects; } \\
\text { shRNA knockdown } \\
\text { leads to failure to } \\
\text { form expanded } \\
\text { blastocyst and } \\
\text { reduced Cdx2 } \\
\text { expression }\end{array}$ & $\begin{array}{l}\text { Expression in ES cells } \\
\text { induces TS cell } \\
\text { differentiation and } \\
\text { XEN-like (primitive } \\
\text { endoderm-like cells) } \\
\text { differentiation }\end{array}$ & $\begin{array}{l}\text { Ma et al. 1997; } \\
\text { Ralston and } \\
\text { Rossant 2008; } \\
\text { Home et al. 2009; } \\
\text { Nishiyama et al. } \\
2009\end{array}$ \\
\hline Klf5 & $\begin{array}{l}\text { Nuclear protein } \\
\text { detectable at 2-cell } \\
\text { stage }\end{array}$ & $\begin{array}{l}\text { Ubiquitous early; } \\
\text { strong in TE, weak in } \\
\text { ICM of blastocysts }\end{array}$ & $\begin{array}{l}\text { Rarely forms blastocyst; } \\
\text { loss of Cdx2 } \\
\text { expression, but still } \\
\text { get repression of } \\
\text { ICM markers in TE }\end{array}$ & $\begin{array}{l}\text { Overexpression in } \\
\text { blastocysts partially } \\
\text { represses endoderm } \\
\text { fate; expression in ES } \\
\text { cells maintains LIF- } \\
\text { independent self- } \\
\text { renewal; expression } \\
\text { with cofactors can } \\
\text { dedifferentiate } \\
\text { fibroblasts into ES- } \\
\text { like cells }\end{array}$ & $\begin{array}{l}\text { Nakagawa et al. } \\
\text { 2008; Niwa et al. } \\
\text { 2009; Lin et al. } \\
2010\end{array}$ \\
\hline
\end{tabular}


Table 1. Continued

\begin{tabular}{|c|c|c|c|c|c|}
\hline Name & Initial expression & Localization & $\begin{array}{l}\text { Loss-of-function } \\
\text { phenotype }\end{array}$ & $\begin{array}{l}\text { Gain-of-function } \\
\text { phenotype }\end{array}$ & References \\
\hline \multicolumn{6}{|c|}{ Primitive endoderm-specific transcription factors } \\
\hline Gata4 & $\begin{array}{l}\text { Nuclear Gata4 protein } \\
\text { detectable in } \sim 64- \\
\text { cell embryos }\end{array}$ & Restricted to PE at E4.5 & $\begin{array}{l}\text { Postimplantation } \\
\text { phenotype; } \\
\text { loss of visceral } \\
\text { endoderm } \\
\text { differentiation in } \\
\text { Gata4-null embryoid } \\
\text { bodies }\end{array}$ & $\begin{array}{l}\text { Expression in ES cells } \\
\text { induces XEN-like } \\
\text { differentiation }\end{array}$ & $\begin{array}{l}\text { Soudais et al. 1995; } \\
\text { Fujikura et al. } \\
\text { 2002; Shimosato } \\
\text { et al. 2007; Plusa } \\
\text { et al. } 2008\end{array}$ \\
\hline Gata6 & $\begin{array}{l}\text { Protein detectable in } \\
\text { some 4-cell embryos }\end{array}$ & $\begin{array}{l}\text { Ubiquitous early; } \\
\text { mosaic in ICM at } \\
\text { E3.5; restricted to PE } \\
\text { at E4.5 }\end{array}$ & $\begin{array}{l}\text { Postimplantation } \\
\text { phenotype; } \\
\text { embryos are growth } \\
\text { retarded and show } \\
\text { defects in } \\
\text { extraembryonic } \\
\text { endoderm gene } \\
\text { expression }\end{array}$ & $\begin{array}{l}\text { Expression in ES cells } \\
\text { induces XEN-like } \\
\text { differentiation }\end{array}$ & $\begin{array}{l}\text { Morrisey et al. 1998; } \\
\text { Fujikura et al. } \\
\text { 2002; Chazaud } \\
\text { et al. 2006; } \\
\text { Shimosato et al. } \\
2007\end{array}$ \\
\hline Sox 17 & $\begin{array}{l}\text { mRNA initiated at } 8 \text { - } \\
\text { cell to blastocyst } \\
\text { stage; protein } \\
\text { observed at morula } \\
\text { stage }\end{array}$ & $\begin{array}{l}\text { Expression mosaic in } \\
\text { early blastocyst; } \\
\text { restricted to PE at } \\
\text { E4.5 }\end{array}$ & $\begin{array}{l}\text { Postimplantation } \\
\text { phenotype; } \\
\text { delayed embryos } \\
\text { with defects in } \\
\text { visceral and } \\
\text { definitive endoderm }\end{array}$ & $\begin{array}{l}\text { Overexpression in ES } \\
\text { cells induces } \\
\text { extraembryonic gene } \\
\text { expression }\end{array}$ & $\begin{array}{l}\text { Kanai-Azuma et al. } \\
\text { 2002; Kim et al. } \\
\text { 2007; Niakan } \\
\text { et al. } 2010\end{array}$ \\
\hline
\end{tabular}

Transcription factors are divided into sections appropriate to the tissue in which they appear to function.

gene, $C d x 2 . \mathrm{Cdx} 2$, in turn is required to promote TE and block pluripotent fate. Cdx2 expression is initiated at low levels in most cells of the embryo from the 8-cell stage on, but becomes up-regulated and restricted exclusively to outer TE progenitors at the late morula/early blastocyst, before Oct4 is restricted to the ICM (Dietrich and Hiiragi 2007; Ralston et al. 2010). Loss of this transcription factor leads to the ectopic expression of ICM markers in the TE and an inability to sustain TE development (Strumpf et al. 2005). In addition, ectopic expression of Cdx2 in ES cells induces TS cell differentiation (Niwa et al. 2005). The early restriction of $\mathrm{Cdx} 2$ expression along with its role in inhibiting the expression of ICM specific transcription factors in the TE indicates that Cdx2 is an essential factor for the divergence of TE and ICM lineages. Two other TFs, Eomes and Gata3, also show TE-restricted expression by the blastocyst stage (Ciruna and Rossant 1999; Home et al. 2009). Knockout of Eomes leads to failure of TE proliferation downstream from Cdx2 (Russ et al. 2000), but Gata3 appears to function in a parallel pathway to Cdx2 (Ralston et al. 2010). All three factors are downstream from the activity of the TEA domain transcription factor Tead4 (Yagi et al. 2007; Nishioka et al. 2008). In Tead4 mutant embryos, Cdx2 expression is almost completely lost, and embryos fail to form any functional TE cells.
Unlike the strict relationship between cell position and cell fate leading up to ICM versus TE formation, within the ICM there does not seem to be a strict relationship between cell position and future cell fate. Rather, all ICM cells begin by coexpressing markers of both EPI and PE lineages, such as Nanog and Gata6, and segregation of expression occurs gradually as the ICM matures (Fig. 2A) (Chazaud et al. 2006; Kurimoto et al. 2006; Plusa et al. 2008; Guo et al. 2010). Individual ICM cells show restricted expression of either EPI or PE markers by the expanded blastocyst stage, without any clear spatial association with the future position of the EPI or PE layers (Chazaud et al. 2006; Plusa et al. 2008). However, cells are not committed to either cell fate until the late blastocyst when the segregation of the PE and EPI is complete (Gardner and Rossant 1979; Artus et al. 2011; Grabarek et al. 2012). The functional roles of the different TFs involved in specifying EPI versus PE fate are not so well worked out as for the ICM/TE decision. Knockout of the pluripotency factor Nanog leads to eventual loss of both EPI and PE (Mitsui et al. 2003; Silva et al. 2009), but loss of PE is cell non-autonomous as shown by its rescue in chimeras (Messerschmidt and Kemler 2010). This suggests that Nanog-expressing cells secrete a factor required for PE formation. Further analysis of Nanog loss of function in the ICM showed that initial expression of Gata6 occurs in Nanog-negative cells, but downstream expression of PE 
R.O. Stephenson et al.

A
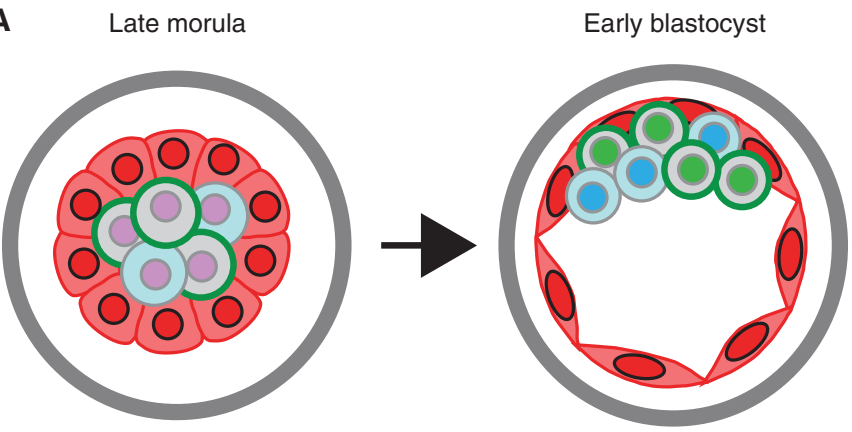

B

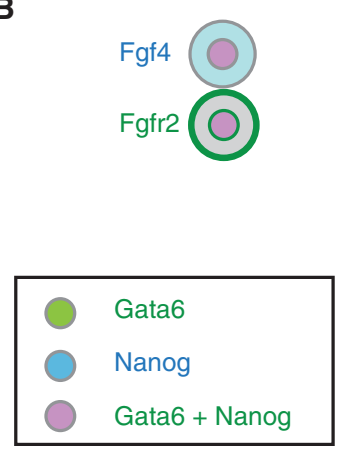

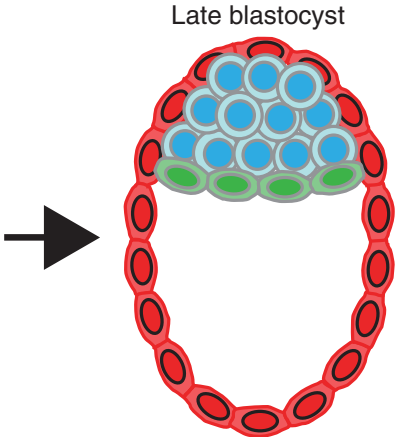
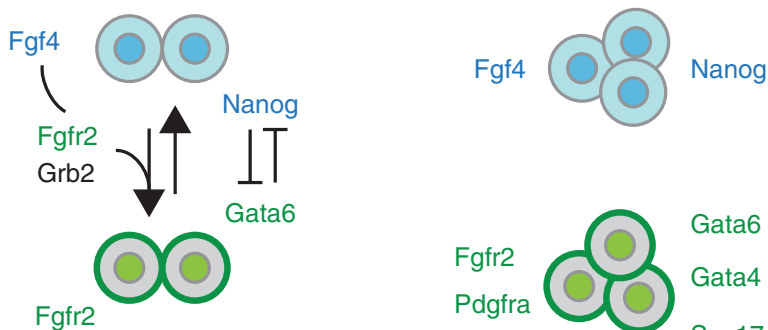

Pdgfra

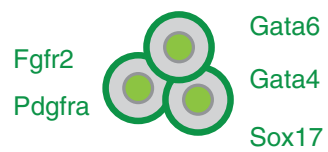

Figure 2. Segregation of primitive endoderm versus epiblast in the inner cell mass. (A) The ICM of the early blastocyst is made up of both EPI (blue) and PE (green) progenitors that express either Nanog or Gata6, respectively. Cell sorting and apoptosis promote proper segregation of PE and EPI to the surface and interior of the ICM. $(B)$ Differential Fgf4/Erk signaling promotes adoption of PE versus EPI fate. Gata6 expression is initiated in a Nanogindependent, but Erk-dependent fashion in the early ICM. In the early blastocyst, Nanog-positive cells secrete Fgf4 ligand, which reinforces Gata6 expression and promotes PE fate in signal-receiving cells. Addition of excess exogenous Fgf4 pushes all ICM cells toward PE fate, whereas inhibition of Fgf/Erk pushes all ICM cells toward EPI fate. Gata6 and Nanog repress one another to promote PE or EPI fate. Gata6 initially promotes PE fate downstream from FGF signaling, but its expression subsequently becomes FGF independent.

markers such as Gata4 and Sox17 requires the presence of wild-type cells (Frankenberg et al. 2011). This suggests a sequential process in which initiation of Nanog and Gata6 is cell autonomous, but stabilization of the PE phenotype requires induction of Gata4 and Sox17 by a signal derived from the Nanog-expressing cells. There is much genetic and pharmacological evidence to identify the signal as Fgf4, as is discussed below. However, the genetic evidence for the hierarchy of TFs involved in PE formation is less clear-cut. Overexpression of either Gata6 or Sox17 in ES cells can drive primitive endoderm differentiation cell autonomously (Fujikura et al. 2002; Shimoda et al. 2007; Shimosato et al. 2007; Niakan et al. 2010). However, individual knockout of either gene does not result in absence of PE formation at the blastocyst (Morrisey et al. 1998; Koutsourakis et al. 1999; Kanai-Azuma et al. 2002; Shimoda et al. 2007). For both Gata6 and Sox17, there are related family members (Gata4 and Sox7) whose expression colocalizes during blastocyst formation (Koutsourakis et al. 1999; Plusa et al. 2008; Artus et al. 2011). Redundancy of function among all these genes may explain the lack of early phenotype in single mutants.

\section{THE RELATIONSHIP BETWEEN MORPHOGENESIS, CELL SIGNALING, AND LINEAGE ALLOCATION IN THE PREIMPLANTATION EMBRYO}

\subsection{ICM versus TE}

The progressive up-regulation of expression of genes like $C d x 2$ and Gata3 in outer cells of the morula/early blastocyst, before the time of final lineage restriction, supports decades-old models that propose cell position and/or cell polarization as the primary cues directing TE versus ICM fates. Initial evidence for cell position as the primary cue for divergence of TE and ICM came from experiments in which 4- and 8-cell blastomeres were dissociated and cultured (Tarkowski and Wroblewska 1967). The investigators observed that as the volume of the embryo decreased, proportionately more cells ended up on the embryo surface and took up a TE fate, while fewer ended up in the embryo 
interior. The investigators thus proposed that the position of a cell in the embryo determines its fate. This proposal has come to be known as the "inside-outside hypothesis" or the "position hypothesis," and has been supported by many experiments showing that changing a cell's position during cleavage stages can affect subsequent fate.

Experiments largely from the group of Martin Johnson in the 1980s proposed a variation on the inside-outside hypothesis known as the polarity model. This derived from the fact that mouse blastomeres undergo de novo apicobasal polarization, beginning at the 8-cell stage. At the 8cell stage, all cells begin to polarize, and the apical domain that is formed at this stage is stable in isolated cells or during cell division (Burgoyne and Ducibella 1977; Johnson and Ziomek 1981b). Stability of the apical domain would enable cells to produce either two outer polar daughters or one outer polar and one inner apolar daughter, depending on the orientation of cleavage during the 816 and 16-32 cell divisions (Johnson and Ziomek 1981a; Balakier and Pedersen 1982; Pedersen et al. 1986; Fleming 1987). The final outcome would be a blastocyst in which the apolar inner cell mass cells have been generated by polarized cell divisions at either the $8-16$ or the $16-32$ cell stage. Outer polarized cells would form the mature tight-junction coupled epithelium of the TE (Johnson and Ziomek 1981b).

The features of polarization in the embryo share many similarities with those of mammalian epithelial cell lines (Ohno 2001; Goldstein and Macara 2007). Ezrin, Pard6b, and the aPKCs (PKCל and PKC $\lambda / \iota$ ) are localized to the apical region of polarized blastomeres, and Par-1, Jam-1, and $\mathrm{Na} / \mathrm{K}$ ATPase are found in the basolateral region, at regions of cell-cell contact (Wang et al. 1990; Louvet et al. 1996; Pauken and Capco 2000; Barcroft et al. 2004; Thomas et al. 2004). Actin and myosin are both enriched in the apical region at the 8-cell stage and subsequently (Sobel 1983a,b; Fleming et al. 1984). Despite apparent similarities in the polarization of mammalian cell lines and early blastomeres, there are important differences. Although E-cadherin-mediated contacts are required for epithelial polarity, early blastomeres are capable of generating an apical domain in the absence of any cell contact (i.e., in isolated blastomeres) (Ziomek and Johnson 1980; Johnson et al. 1986). In embryos completely lacking E-cadherin, cells do express apical markers, but the correct segregation of apical and basolateral domains is disrupted (Stephenson et al. 2010). Another striking difference between the polarization of mammalian cell lines and preimplantation blastomeres is the axis of polarization. In MDCK or Caco-2 cell lines (kidney and colorectal cells, respectively), epithelial cysts form when cells are cultured in three-dimensional (3D) matrices. The apical domain forms in the core of the cyst, and the basolateral domains of cells make up the surface of the cyst (Jaffe et al. 2008). However, the polarity of MDCK cells is inverted when aggregates are generated in suspension culture (rather than in Matrigel). Here the apical domain forms on the surface of the cyst, much like in blastocysts (Wang et al. 1990).

The other striking difference between epithelialization in cell lines and in the early embryo is that epithelial cysts are hollow, whereas the mouse embryo has an outer layer of polarized cells and an inner group of apolar cells that do not express the apical domain markers. Johnson proposed that individual blastomeres would divide symmetrically or asymmetrically dependent on whether the mitotic spindle was parallel or perpendicular to the apical domain. Symmetric divisions would split the stable apical domain and generate two polar cells, whereas asymmetric divisions would generate an outer polar and an inner apolar cell. Although there is no predetermined ratio of asymmetric versus symmetric divisions at each division round, the embryo somehow adjusts the proportions of cells to end up with a fairly consistent number of ICM and TE cells at the blastocyst stage (Fleming 1987). In more recent years, as imaging techniques have improved, the strict relationship proposed between inheritance of the apical domain and TE formation has become more nuanced. It has been shown that the mitotic spindle orientation is not strictly regulated (Dard et al. 2009) and that cells can divide in different orientations and still go on to generate inner and outer cells (McDole et al. 2011). Cell shape and mechanical forces seem to play a key role in ensuring the final disposition of inner and outer cells. In isolated cell pairs, a polar cell will engulf an apolar cell, and surface cells will re-sort to the surface when placed in inner positions in blastomere aggregates (Ziomek and Johnson 1982; Johnson and Ziomek 1983; Surani and Handyside 1983). This property, when translated to the intact embryo, will ensure that cells will distribute correctly to inner or outer positions regardless of their initial location after cell division. This sorting of cells to inner and outer compartments likely reflects their physical properties, rather than any early commitment of cell fate to TE or ICM. In support of this, recent work suggests that surface cells from 16-cell embryos and even 32-cell embryos can contribute exclusively to the ICM lineage if they are aggregated with large numbers of tetraploid cells (Tarkowski et al. 2010). A single blastomere of the 32-cell embryo can even generate an entire E9.5 embryo.

In many ways, the distinction between the position hypothesis and the polarity hypothesis is an artificial one. It is the formation of an outer polarized epithelium that ensures the development of an increasingly stable inside environment in the embryo, allowing differential signaling dependent on cell position. Recent evidence that the Hippo 
signaling pathway plays a key role in driving ICM versus TE fate provides the potential mechanism to link the two hypotheses. Expression of $C d x 2$ and formation of the TE is absolutely dependent on the transcription factor Tead 4 and its coactivator partner, Yap1 (Yagi et al. 2007; Nishioka et al. 2008, 2009). Although Tead 4 and Yap1 are expressed in all of the cells of the preimplantation embryo, Yap1 is only localized to the nucleus in the developing outer cells, overlapping with $C d x 2$ expression (Nishioka et al. 2009). Yap1 was shown to be phosphorylated by activity of the Hippo signaling pathway kinase, Lats $1 / 2$, in the inner cells, leading to Yap 1 cytoplasmic sequestration and hence absence of Tead4 activity in inner cells (Fig. 3) (Nishioka et al. 2009). This posttranscriptional method of ensuring the restricted expression of $C d x 2$ can explain the initiation of cell fate specification leading up to the blastocyst. The inhibition of TE versus ICM by the reciprocal action of Cdx 2 and Oct 4 at the blastocyst stage provides the means of ensuring ongoing lineage restriction (Niwa et al. 2005).

The close association between restriction of Yap1 nuclear localization, $C d x 2$ expression, and formation of the outer polarized epithelium raise the question of whether there is a causal link between cell polarity, epithelium formation, and TE cell fate. A recent study of embryos lacking both maternal and zygotic E-cadherin confirmed that an organized polar epithelium cannot be formed in the absence of E-cadherin. However, $\mathrm{Cdx} 2$ was expressed in the resulting aggregates of cells, with an increased rather than decreased proportion of cells showing Cdx2 versus Oct4 expression (Stephenson et al. 2010). Furthermore, there were very few cells in these mutants where Yap was excluded from the nucleus, suggesting that in the absence of cell adhesion

A

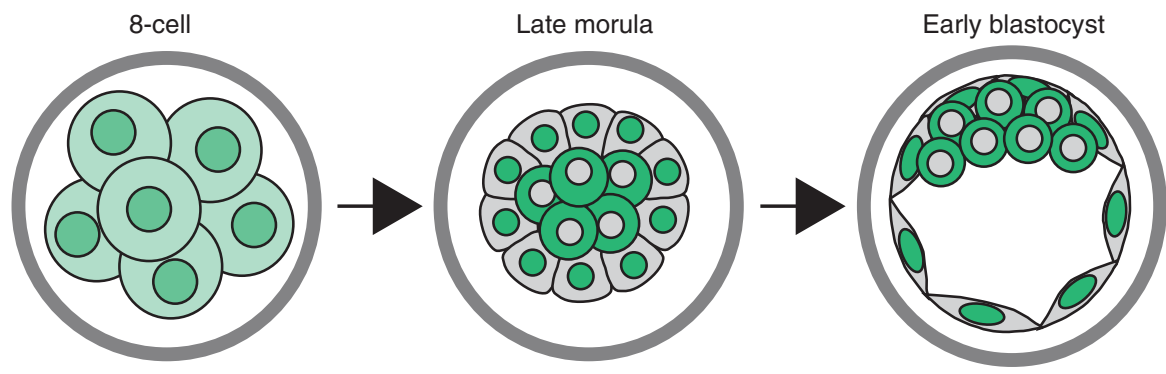

Yap

B

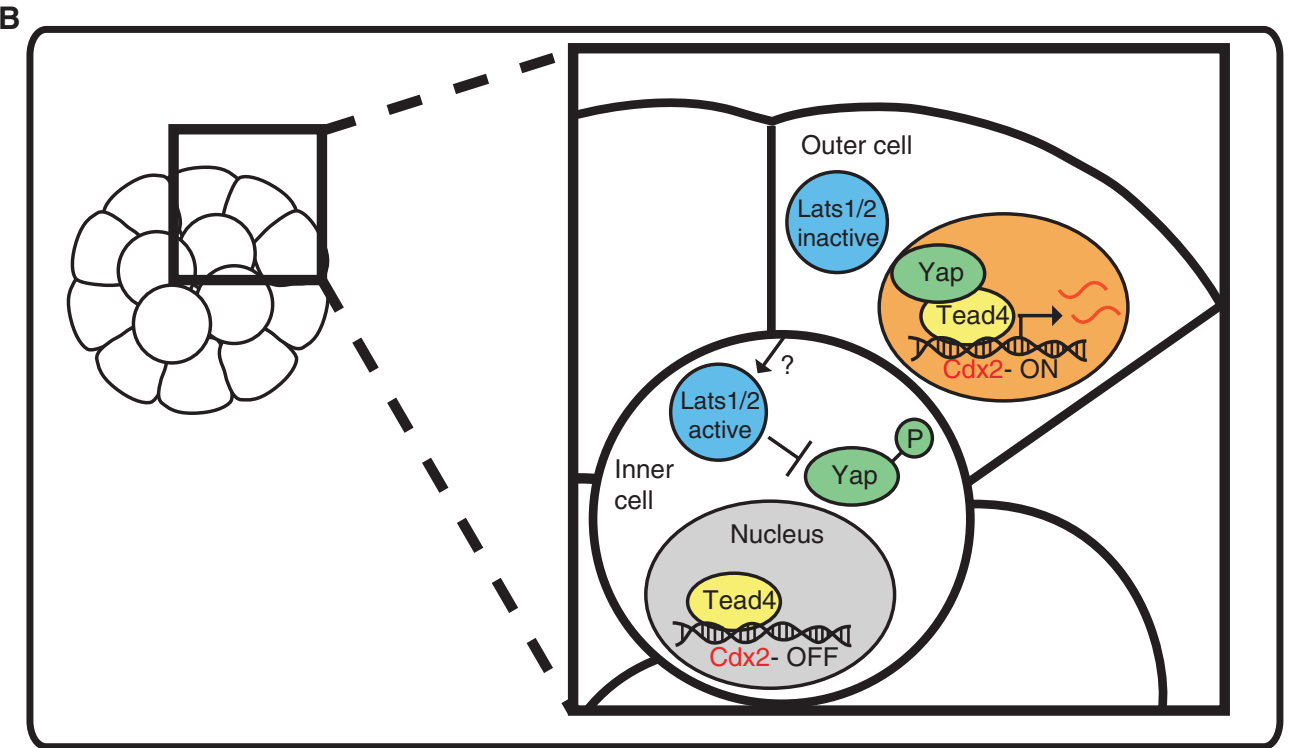

Figure 3. Restriction of trophectoderm-specific gene expression in the blastocyst. (A) Yap1 is found in the nuclei and weakly within the cytoplasm of all cells at the 8-cell stage. By the late morula stage, Yap1 is restricted to the nucleus of cells on the surface of the embryo and found in the cytoplasm of cells in the embryo interior. (B) In outer cells, Lats kinase is inactive and Yap1 is not phosphorylated. This permits Yap1 translocation into the nucleus, where it associates with Tead4 and promotes Cdx2 expression. Unknown cell contact-related factors promote activation of Lats kinase in inner cells, where it phosphorylates Yap1, preventing its entry into the nucleus. 
and an organized outer epithelium, there is no activation of Hippo signaling. Thus, the main role of the polarized outer epithelium could be simply to ensure that inner cells are maintained in a stable environment long enough to activate Hippo signaling and block Cdx2 expression.

However, other studies have shown a direct link between apical-basal polarization and cell specification. Notably, disruption of the activity of proteins localized to the apical pole, Par-3, and PKC $\lambda$ can direct the progeny of early blastomeres preferentially to the inside of the embryo (Plusa et al. 2005). Knockdown of Pard6b RNA also reduces Cdx2 expression in outer cells, suggesting that polarization is upstream of lineage-specific transcription factor expression (Alarcon 2010). In addition, when inner apolar cells are isolated, they can repolarize (Johnson and Ziomek 1983; Eckert et al. 2004) and re-express Cdx2 (Suwinska et al. 2008; Stephenson et al. 2010), again supporting this close correlation between polarity and lineage specification.

In $C d x 2$ mutants, initial polarization occurs, but the outer polarized epithelium fails to be maintained, suggesting that $\mathrm{Cdx} 2$ is not required to initiate polarity (Strumpf et al. 2005). Although recent studies suggest the existence of maternal $C d x 2$, they disagree whether it plays a further role in preimplantation development (Jedrusik et al. 2010; Wu et al. 2010). Another study has suggested that increased expression of $\mathrm{Cdx} 2$ could polarize cells and bias them toward TE fate, whereas reduced expression of $\mathrm{Cdx} 2$ led to blastomeres being preferentially allocated to the ICM (Jedrusik et al. 2008). However, no similar bias was observed when $C d x 2$ mutant blastomeres were mixed with wild-type cells in chimeric aggregates (Ralston and Rossant 2008). It is therefore still unclear whether polarization drives the TE differentiation program or whether $\mathrm{Cdx} 2$ expression drives morphogenetic changes associated with TE fate.

It has also been suggested that there may be intrinsic biases even earlier in development that could predispose cells to become ICM or TE. At the 4-cell stage, all blastomeres from one embryo were dissociated and each found to be capable of generating TE, EPI, and PE when aggregated with carrier blastomeres (Kelly 1977). Owing to the extreme technical difficulty of this experiment, however, it has not been replicated using blastomeres from embryos at the 8-cell stage onward. More recent experiments have suggested that individual blastomeres at the 4-cell stage might have different potentials. More specifically, a particular 4-cell blastomere, defined by its position during cleavage to the 4-cell stage, is reported to show a bias toward the mural TE (Piotrowska-Nitsche et al. 2005). Four-cell blastomeres that contribute primarily to mural TE were found to express higher levels of $C d x 2$, lower levels of Nanog, and have lower levels of histone arginine methylation than their sisters (Torres-Padilla et al. 2007a; Jedrusik et al. 2008). It has been proposed that increased levels of Carm1, the histone arginine methyltransferase, lead to reduced expression of apical markers and thus promote inner cell localization (Parfitt and Zernicka-Goetz 2010).

Although all of these studies implicate a close association between cell polarity and cell fate, the exact mechanistic interaction between cell polarity, Hippo signaling, and cell fate remains to be determined (Fig. 3). There is a complex interplay between activation of the Hippo signaling pathway and apicobasal polarity proteins in both Drosophila and mammalian epithelial cells (Genevet and Tapon 2011). Cell shape, extracellular matrix rigidity, and the tension of the actomyosin cytoskeleton have also been implicated in regulating Yap nuclear localization (Dupont et al. 2011; Wada et al. 2011). Given the known association between cell morphology, cell engulfment, and the generation of the inner and outer cell populations, there is clearly need for more analysis of the relationship between the physical events of compaction and epithelium formation and the downstream events that localize Yap. Further studies on the involvement of the various upstream components of the Hippo signaling pathway, such as Merlin, expanded, Fat and Dachsous, are under way and should reveal more of the complex interplay between cell polarity, cell contact, cell position, and cell fate in blastocyst development.

\subsection{Segregation of EPI and PE}

Although cell position clearly plays a role in directing cells to ICM versus TE fates and in constraining the number of cells to these respective compartments, the next lineage decision appears to be undertaken in a much more stochastic manner. There is increasing evidence that FGF signaling levels received by individual ICM cells determine the likelihood of a cell becoming EPI or PE (Fig. 2). Although there is no single TF mutation that causes complete absence of the PE, loss of the adaptor protein Grb2, which links receptor tyrosine kinases (RTKs) to the Ras-MAP kinase signaling pathway, does cause such a phenotype (Cheng et al. 1998). In $\mathrm{Grb2}^{-/-}$blastocysts, ICM cell number is normal but all cells express EPI markers, like Nanog, and no expression of Gata6 is observed (Chazaud et al. 2006). This suggests strongly that RTK signaling through the Ras-MAP kinase pathway is required to initiate $\mathrm{PE}$ gene expression in the ICM. Several pieces of evidence suggested that the candidate upstream RTK signal is Fgf4 acting through Fgfr2. Both genes are expressed in the developing ICM, and their expression is seen to segregate to EPI and PE progenitors, respectively, by single-cell PCR analysis as the ICM matures (Kurimoto et al. 2006; Guo et al. 2010). Mutation of Fgf4 leads to peri-implantation defects in the ICM with reduced PE development (Feldman et al. 1995; 
Goldin and Papaioannou 2003). Fgfr2 mutant mice fail to generate PE (Arman et al. 1998). Inhibitor treatments targeting either FGF receptors or the downstream MAP kinase pathway phenocopy the loss of Grb2 (Nichols et al. 2009; Yamanaka et al. 2010). All of this suggests that FGF signaling through the Ras-MAP kinase pathway is necessary for PE formation. However, this could be a permissive signal allowing the initiation of PE development. Evidence for an instructive role for FGF signaling was provided by the demonstration that incubation of blastocysts in excess levels of Fgf4 could produce the opposite phenotype, namely, turning all ICM cells into PE progenitors with loss of EPI cells (Yamanaka et al. 2010). Careful timed treatments showed that the window of sensitivity to excess Fgf or Fgfr inhibition was concomitant with the period when the ICM cells were gradually shifting toward lineage-restricted gene expression (Yamanaka et al. 2010; Frankenberg et al. 2011). This suggests that the ICM cells are individually responding to local FGF levels in the blastocyst by differentiating into EPI or PE cells. Recent work has confirmed Nanog-positive EPI progenitors as the source of Fgf4 signal (Frankenberg et al. 2011). Thus in Nanog mutant embryos, PE fate is initiated in the ICM, but because of the absence of Fgf4 production, mature $\mathrm{PE}$ is not formed. This defect can be rescued by the incorporation of wild-type cells into Nanognull blastocysts (Messerschmidt and Kemler 2010; Frankenberg et al. 2011). How this signal is translated into downstream restriction at the transcription factor level is currently unknown. Downstream from this initial variable response to FGF levels, cells must also activate pathways that lead to differential cell surface properties of the EPI and PE cells, so that the initial mosaic, stochastic response to local FGF signals can be translated into segregation of the final committed EPI and PE lineages. Candidate downstream genes include Dab2 (Yang et al. 2002), Maspin (Gao et al. 2004), Lamc1 (Murray and Edgar 2001), and Itgb1 (integrin $\beta 1$ ) (Stephens et al. 1995), whose mutant phenotypes leave PE-like cells scattered within the ICM.

Although the formation of the EPI and PE progenitors is not initiated in a strict position-dependent manner, the processes of polarized cell divisions that lead up to blastocyst formation may play a role in biasing inner cells toward either EPI or PE fate. One of the puzzles of the current model whereby individual cells in the ICM respond to local levels of FGF to become EPI or PE is to explain how initial mosaicism of FGF signal can be achieved. It is certainly possible that this is entirely stochastic; several models of stochastic gene expression leading progressively to stable differences in gene expression have recently been proposed (Chickarmane and Peterson 2008; Enver et al. 2009; Hallen et al. 2011). However, it is also possible that inner cells are biased toward EPI or PE, dependent on whether they entered the inner region at the $8-16$ or $16-32$ cell division. Given that the outer cells are maturing toward a fully functional polarized epithelium over this time period, one could envisage that inner cells generated at the two cleavage divisions could inherit different starting levels of FGF receptors or ligands and thus be biased toward being a source or a responder of the key FGF signal. Two recent studies used lineage-tracing techniques to address this issue. One found that the first round of inner cells could contribute equally to EPI or PE but that the second round of cells was biased toward PE (Morris et al. 2010). Using a different approach, the second group could not detect any clear bias toward one cell type or another (Yamanaka et al. 2010). Regardless of why the results were different, in both studies, there was no evidence of rigid lineage-driven differentiation. In addition, because manipulating FGF levels at the blastocyst stage can totally shift cell fate, any bias associated with cell lineage can readily be overridden. Clearly, more work is needed to explain how the intriguing mosaicism of progenitors in the ICM is established and transformed into the appropriate restricted cell layers in an orderly manner.

\section{RELATIONSHIP OF CELL FATES AND THE ARCHITECTURE OF THE BLASTOCYST WITH THE PATTERNING OF THE POSTIMPLANTATION EMBRYO}

\subsection{Emergence of the Proximal-Distal Axis}

The acquisition of different lineage properties and the segregation of epiblast and primitive endoderm transform the architecture of the ICM. It now consists of a cellular cluster closely apposed to the polar trophectoderm and an epithelium facing the blastocyst cavity. The diametric axis spanning from the ICM and the non-ICM side of the blastocyst constitutes the embryonic-abembryonic (Emb-Abemb) axis of the blastocyst. Following implantation into the uterine tissue, the polar trophectoderm, epiblast, and the primitive endoderm grow into the blastocyst cavity to form a cylindrical embryo, the egg cylinder (Fig. 1B). The EmbAbemb axis of the blastocyst thus becomes the proximal (the pole with the TE-derived ectoplacental cone)-distal axis (PD axis) of the egg cylinder. The epiblast undergoes cavitation and epithelialization and is reconfigured into a laminar tissue enclosing a central (proamniotic) cavity (Rossant and Tam 2009).

\subsection{Asymmetry of the Blastocyst: Readout of Embryonic Patterning?}

The mouse blastocyst is not perfectly spherical but is asymmetrical in its shape (laterally flattened), the position of the 
ICM in the embryonic pole (off center of the Emb-Abemb axis), the shape of the ICM (lopsided), and the position of the remnant of the second polar body (orthogonal to the Emb-Abemb axis) (for review, see Rossant and Tam 2009). It is still not clear if any of these structural asymmetries has any bearing on the determination of the PD or transverse axes of the egg cylinder or the primary body axes (DV, anterior-posterior: AP; left-right: LR) of more advanced postimplantation embryos.

The relationship of the position of the second polar body to the axes of the egg cylinder has been examined by tracing the distribution of the clonal descendants of ICM cells that are localized near or away from the polar body (Weber et al. 1999). When embryos were harvested and examined at different times of intrauterine development following blastocyst transfer, visceral endoderm clones of ICM cells near or away from the polar body were found to be localized differentially in the PD and transverse planes of the egg cylinder. It was suggested that the axis that is orthogonal to the Emb-Abemb axis and marked at one pole by the polar body may be the forerunner of the PD axis of the egg cylinder (Weber et al. 1999), which is re-aligned subsequently with the AP axis of the embryo (Beddington and Robertson 1999). A potential caveat of the interpretation of these findings is that the position of the clone relative to the putative axes of the egg cylinder was judged by the shape of the embryo. It has been shown that the morphology of the egg cylinder is not a reliable readout of the orientation of the AP axis of the embryos (Rossant and Tam 2009). In particular, the shape of the egg cylinder in the transverse plane changes during pre-gastrulation development, such that the putative AP axis aligns first with the short and then with the long diameter of the transverse plane of the egg cylinder (Mesnard et al. 2004; Perea-Gomez et al. 2004; Tam 2004; Guo and Li 2007). Before any conclusion can be made of the relationship between the polar body-defined axis and the embryonic axis, these experiments would have to be revisited by assessing the spatial distribution of the clones using the domain of expression of genetic markers that are expressed asymmetrically in the egg cylinder (Pfister et al. 2007) as the reference landmark.

\subsection{Regionalized Genetic and Signaling Activity in the Blastocyst}

Within the epiblast and primitive endoderm, cells appear to display no discernible regionalized expression of genes coding for lineage-specific transcription factors, for example, Oct4, Nanog, Gata4, Gata6, and Sox17. However, individual cells may express varying levels of genes coding for factors or mediators of signaling activity, for example,
Pdgfra, Fgf4, Fgfr2, Lefty1, Nodal, Wnt9a, and $\beta$-catenin. It is therefore possible that cells in the epiblast and the primitive endoderm may be subject to varying levels of signaling activity that may underpin tissue patterning pertaining to axis determination.

With the exception of Lefty1- and Cer1-expressing cells, no detailed information is available on the localization of cells in the epiblast or primitive endoderm that may be engaged with signaling activity. Cells expressing Lefty 1 or Cerl are initially dispersed among the ICM cells, and these early Lefty $1^{+}$cells are not committed to PE. A second wave of Lefty $1^{+}$(and Gata6 $^{+}$) cells is subsequently confined to the primitive endoderm (Torres-Padilla et al. 2007b; Takaoka et al. 2011). It is likely that these cells are sorted from epiblast cells along with other cells that are fated to become primitive endoderm (Meilhac et al. 2009; Artus et al. 2011). In the primitive endoderm, Lefty $1^{+}$cells seem not to be distributed randomly but are localized to one side of the epithelium. It has been speculated that the location of the Lefty $1^{+}$cells marks the prospective anterior side of the embryo, but this has yet to be proven experimentally. Blastocysts grown in vitro to past the equivalent stage of implantation in vivo display asymmetrical localization of the Lefty ${ }^{+}$primitive endoderm (Takaoka et al. 2006). This has been taken as evidence supporting the concept that acquisition of this asymmetrical feature of the blastocyst is independent of any tissue interaction with the uterine tissue or developmental cues in the intrauterine environment. It also highlights that the breaking of symmetry in the blastocyst may not be associated with the physical action of implantation (Rossant and Tam 2009).

\subsection{Early Allocation of Distal Visceral Endoderm Is a Prelude to the Formation of PD Axis}

Lineage-tracing experiments have revealed that the Lefty1expressing primitive endoderm cells are the precursors of the cells that populate the distal visceral endoderm (DVE) of the egg cylinder (Takaoka et al. 2011). This finding raises the possibility that either the Lefyt1-expressing DVE precursors are endowed with the positional information for establishing the distal pole of the PD axis or that they are responding to the pre-set morphogenetic signals that navigate their movement and guide their differentiation. It may also suggest that the determination of the PD axis occurs early in the blastocyst.

Interestingly, DVE cells do not appear to form the AVE, which is formed instead by the activation of AVE/DVE genes in the visceral endoderm in the vicinity of the DVE (Rodriguez et al. 2005; Torres-Padilla et al. 2007b; Yamamoto et al. 2009; Takaoka et al. 2011). It is not clear whether the DVE itself provides the inductive signal or whether its 
presence reflects the underlying landscape of Nodal or BMP signaling activity that permits the generation of the AVE precursors. Physical or genetic ablation of the Lefty1expressing DVE does not affect the formation of the AVE, suggesting that DVE is not necessary for the generation of AVE. The presence of Lefty $1^{+}$DVE, however, seems essential for initiating the movement of the AVE cells: Both populations move in concert to the prospective anterior side of the egg cylinder (Takaoka et al. 2011). Whereas the AVE cells will halt when the leading cells reach the site defined by the proximal border of the epiblast (Rivera-Perez et al. 2003; Srinivas et al. 2004; Takaoka et al. 2011), the DVE cells turn and continue to track a lateral and distal route (Takaoka et al. 2011). Presently, the cellular and molecular mechanism underpinning the anterior-proximal movement of the AVE and DVE and the different migratory behavior of the two VE cell populations are not understood. Differences in the level of signaling activity, principally of Wnt and Nodal, that impact on cellular architecture (shape, protrusion formation, and cytoskeletal changes), motility, and proliferation, are reputed to play a role in the navigation of AVE/DVE cells. However, real-time imaging reveals that cells in the visceral endoderm display a pattern of displacement from distal to anterior-proximal and anterior-proximal to lateral-posterior and distal sites, resulting in a swirling movement of cells in the endoderm epithelium (Weber et al. 1999; Tam et al. 2001; Takaoka et al. 2011). This complex pattern of cell movement would have to be controlled by more than a simplistic mechanism of a graded signaling activity across one dimension of the egg cylinder.

The finding that DVE can influence the movement and localization of the AVE highlights the concept that the allocation of a specific population of the primitive endoderm cells to the DVE precursors launches the process of patterning the postimplantation embryo. A proper positioning and function of the AVE, enabled by the yet unidentified activity of the DVE, are required for the regionalization of the developmental fate of the epiblast, through input by the AVE cells into an interplay of signaling cascades involving Nodal, BMPs, and Wnt (Tam et al. 2006; Shen 2007; Tam and Loebel 2007; Takaoka and Hamada 2012). Consequently, cells that are impacted by the AVE acquire anterior fate (contributing to head and brain structures), whereas those away from the AVE acquire posterior fate (forming the mesoderm and endoderm via the morphogenetic activity at the primitive streak).

\section{CONCLUSIONS AND FUTURE DIRECTIONS}

We propose that further studies involving detailed imaging of molecular events at the single-embryo and single-cell level hold promise to make the mouse blastocyst one of the best-understood models of embryonic cell lineage development. However, the linkage between blastocyst lineage segregation and the subsequent events of body axis formation is still unclear. There is presently no compelling evidence that the placement of cells that express lineagespecific gene activity in the primitive endoderm or the epiblast has any association with the pre-setting of the embryonic axis or body plan. It is nevertheless conceivable that the process of embryonic patterning could have been initiated during the formation of the blastocyst and that the primitive endoderm of the blastocyst and its descendants in the visceral endoderm are the repository and the source of the morphogenetic signals for axis determination. For future investigations, it would be imperative to explore the developmental mechanism of (1) the specification of cell types in the blastocyst that are endowed with patterning activity, such as the DVE precursors; (2) the morphogenetic process undertaken by these cells to specify the PD and subsequently the AP axis of the embryo; and (3) the establishment of the morphogenetic landscape that is first manifested by the congregation of the DVE to the distal site of the egg cylinder and then the directed movement of AVE/ DVE to the prospective anterior side of the embryo. Some useful mechanistic clues may be gleaned by re-analyzing the phenotype of existing gene-targeted mutant mice that display AP patterning defects during peri-implantation development, as well as by a focused screen of mutant mice generated by chemical mutagenesis that are reputed to display peri-implantation developmental arrest or lethality.

\section{REFERENCES}

* Reference is also in this collection.

Alarcon VB. 2010. Cell polarity regulator PARD6B is essential for trophectoderm formation in the preimplantation mouse embryo. Biol Reprod 83: 347-358.

Arman E, Haffner-Krausz R, Chen Y, Heath JK, Lonai P. 1998. Targeted disruption of fibroblast growth factor (FGF) receptor 2 suggests a role for FGF signaling in pregastrulation mammalian development. Proc Natl Acad Sci 95: 5082-5087.

Artus J, Piliszek A, Hadjantonakis AK. 2011. The primitive endoderm lineage of the mouse blastocyst: Sequential transcription factor activation and regulation of differentiation by Sox17. Dev Biol 350: 393-404.

Avilion AA, Nicolis SK, Pevny LH, Perez L, Vivian N, Lovell-Badge R. 2003. Multipotent cell lineages in early mouse development depend on SOX2 function. Genes Dev 17: 126-140.

Balakier H, Pedersen RA. 1982. Allocation of cells to inner cell mass and trophectoderm lineages in preimplantation mouse embryos. Dev Biol 90: $352-362$.

Barcroft LC, Moseley AE, Lingrel JB, Watson AJ. 2004. Deletion of the $\mathrm{Na} / \mathrm{K}$-ATPase $\alpha 1$-subunit gene (Atpla1) does not prevent cavitation of the preimplantation mouse embryo. Mech Dev 121: $417-426$ 
Beddington RS, Robertson EJ. 1999. Axis development and early asymmetry in mammals. Cell 96: 195-209.

Burgoyne PS, Ducibella T. 1977. Changes in the properties of the developing trophoblast of preimplantation mouse embryos as revealed by aggregation studies. J Embryol Exp Morphol 40: 143-155.

Chambers I, Silva J, Colby D, Nichols J, Nijmeijer B, Robertson M, Vrana J, Jones K, Grotewold L, Smith A. 2007. Nanog safeguards pluripotency and mediates germline development. Nature 450: 1230-1234.

Chazaud C, Yamanaka Y, Pawson T, Rossant J. 2006. Early lineage segregation between epiblast and primitive endoderm in mouse blastocysts through the Grb2-MAPK pathway. Dev Cell 10: 615-624.

Cheng AM, Saxton TM, Sakai R, Kulkarni S, Mbamalu G, Vogel W, Tortorice CG, Cardiff RD, Cross JC, Muller WJ, et al. 1998. Mammalian Grb2 regulates multiple steps in embryonic development and malignant transformation. Cell 95: 793-803.

Chickarmane V, Peterson C. 2008. A computational model for understanding stem cell, trophectoderm and endoderm lineage determination. PLOS ONE 3: e3478.

Ciruna BG, Rossant J. 1999. Expression of the T-box gene Eomesodermin during early mouse development. Mech Dev 81: 199-203.

Dard N, Le T, Maro B, Louvet-Vallee S. 2009. Inactivation of aPKC $\lambda$ reveals a context dependent allocation of cell lineages in preimplantation mouse embryos. PLoS ONE 4: e7117.

Dietrich JE, Hiiragi T. 2007. Stochastic patterning in the mouse preimplantation embryo. Development 134: 4219-4231.

Ducibella T, Ukena T, Karnovsky M, Anderson E. 1977. Changes in cell surface and cortical cytoplasmic organization during early embryogenesis in the preimplantation mouse embryo. J Cell Biol 74: 153-167.

Dupont S, Morsut L, Aragona M, Enzo E, Giulitti S, Cordenonsi M, Zanconato F, Le Digabel J, Forcato M, Bicciato S, et al. 2011. Role of YAP/TAZ in mechanotransduction. Nature 474: 179-183.

Eckert JJ, McCallum A, Mears A, Rumsby MG, Cameron IT, Fleming TP. 2004. PKC signalling regulates tight junction membrane assembly in the pre-implantation mouse embryo. Reproduction 127: 653-667.

Ema M, Mori D, Niwa H, Hasegawa Y, Yamanaka Y, Hitoshi S, Mimura J, Kawabe Y, Hosoya T, Morita M, et al. 2008. Kruppel-like factor 5 is essential for blastocyst development and the normal self-renewal of mouse ESCs. Cell Stem Cell 3: 555-567.

Enver T, Pera M, Peterson C, Andrews PW. 2009. Stem cell states, fates, and the rules of attraction. Cell Stem Cell 4: 387-397.

Feldman B, Poueymirou W, Papaioannou VE, DeChiara TM, Goldfarb M. 1995. Requirement of FGF-4 for postimplantation mouse development. Science 267: 246-249.

Fleming TP. 1987. A quantitative analysis of cell allocation to trophectoderm and inner cell mass in the mouse blastocyst. Dev Biol 119: 520531.

Fleming TP, Johnson MH. 1988. From egg to epithelium. Ann Rev Cell Biol 4: 459-485.

Fleming TP, Warren PD, Chisholm JC, Johnson MH. 1984. Trophectodermal processes regulate the expression of totipotency within the inner cell mass of the mouse expanding blastocyst. J Embryol Exp Morphol 84: 63-90.

Fleming TP, Papenbrock T, Fesenko I, Hausen P, Sheth B. 2000. Assembly of tight junctions during early vertebrate development. Semin Cell Dev Biol 11: 291-299.

Frankenberg S, Gerbe F, Bessonnard S, Belville C, Pouchin P, Bardot O, Chazaud C. 2011. Primitive endoderm differentiates via a three-step mechanism involving Nanog and RTK signaling. Dev Cell 21: 10051013.

Fujikura J, Yamato E, Yonemura S, Hosoda K, Masui S, Nakao K, Miyazaki J-I, Niwa H. 2002. Differentiation of embryonic stem cells is induced by GATA factors. Genes Dev 16: 784-789.

Gao F, Shi HY, Daughty C, Cella N, Zhang M. 2004. Maspin plays an essential role in early embryonic development. Development 131: $1479-1489$.
Gardner RL, Rossant J. 1979. Investigation of the fate of 4-5 day postcoitum mouse inner cell mass cells by blastocyst injection. J Embryol Exp Morphol 52: 141-152.

Genevet A, Tapon N. 2011. The Hippo pathway and apico-basal cell polarity. Biochem J 436: 213-224.

Goldin SN, Papaioannou VE. 2003. Paracrine action of FGF4 during periimplantation development maintains trophectoderm and primitive endoderm. Genesis 36: 40-47.

Goldstein B, Macara IG. 2007. The PAR proteins: Fundamental players in animal cell polarization. Dev Cell 13: 609-622.

Grabarek JB, Zyzynska K, Saiz N, Piliszek A, Frankenberg S, Nichols J, Hadjantonakis AK, Plusa B. 2012. Differential plasticity of epiblast and primitive endoderm precursors within the ICM of the early mouse embryo. Development 139: 129-139.

Guo Q, Li JY. 2007. Distinct functions of the major Fgf8 spliceform, Fgf8b, before and during mouse gastrulation. Development 134: $2251-2260$.

Guo G, Huss M, Tong GQ, Wang C, Sun LL, Clarke ND, Robson P. 2010. Resolution of cell fate decisions revealed by single-cell gene expression analysis from zygote to blastocyst. Dev Cell 18: 675-685.

Hallen M, Li B, Tanouchi Y, Tan C, West M, You L. 2011. Computation of steady-state probability distributions in stochastic models of cellular networks. PLoS Comput Biol 7: e1002209.

Handyside AH. 1980. Distribution of antibody- and lectin-binding sites on dissociated blastomeres from mouse morulae: Evidence for polarization at compaction. J Embryol Exp Morphol 60: 99-116.

Home P, Ray S, Dutta D, Bronshteyn I, Larson M, Paul S. 2009. GATA3 is selectively expressed in the trophectoderm of peri-implantation embryo and directly regulates Cdx2 gene expression. J Biol Chem 284: 28729-28737.

Jaffe AB, Kaji N, Durgan J, Hall A. 2008. Cdc42 controls spindle orientation to position the apical surface during epithelial morphogenesis. J Cell Biol 183: 625-633.

Jedrusik A, Parfitt DE, Guo G, Skamagki M, Grabarek JB, Johnson MH, Robson P, Zernicka-Goetz M. 2008. Role of Cdx2 and cell polarity in cell allocation and specification of trophectoderm and inner cell mass in the mouse embryo. Genes Dev 22: 2692-2706.

Jedrusik A, Bruce AW, Tan MH, Leong DE, Skamagki M, Yao M, Zernicka-Goetz M. 2010. Maternally and zygotically provided Cdx2 have novel and critical roles for early development of the mouse embryo. Dev Biol 344: 66-78.

Johnson MH, Ziomek CA. 1981a. Induction of polarity in mouse 8-cell blastomeres: Specificity, geometry, and stability. J Cell Biol 91: 303308.

Johnson MH, Ziomek CA. 1981b. The foundation of two distinct cell lineages within the mouse morula. Cell 24: 71-80.

Johnson MH, Ziomek CA. 1983. Cell interactions influence the fate of mouse blastomeres undergoing the transition from the 16- to the 32cell stage. Dev Biol 95: 211-218.

Johnson MH, Maro B, Takeichi M. 1986. The role of cell adhesion in the synchronization and orientation of polarization in 8-cell mouse blastomeres. J Embryol Exp Morphol 93: 239-255.

Kanai-Azuma M, Kanai Y, Gad JM, Tajima Y, Taya C, Kurohmaru M, Sanai Y, Yonekawa H, Yazaki K, Tam PP, et al. 2002. Depletion of definitive gut endoderm in Sox17-null mutant mice. Development 129: $2367-2379$.

Kelly SJ. 1977. Studies of the developmental potential of 4- and 8-cell stage mouse blastomeres. J Exp Zool 200: 365-376.

Kim I, Saunders TL, Morrison SJ. 2007. Sox17 dependence distinguishes the transcriptional regulation of fetal from adult hematopoietic stem cells. Cell 130: 470-483.

Koutsourakis M, Langeveld A, Patient R, Beddington R, Grosveld F. 1999. The transcription factor GATA6 is essential for early extraembryonic development. Development 126: 723-732.

Kurimoto K, Yabuta Y, Ohinata Y, Ono Y, Uno KD, Yamada RG, Ueda HR, Saitou M. 2006. An improved single-cell cDNA amplification method 
R.O. Stephenson et al.

for efficient high-density oligonucleotide microarray analysis. Nucleic Acids Res 34: e42.

Lin SC, Wani MA, Whitsett JA, Wells JM. 2010. Klf5 regulates lineage formation in the pre-implantation mouse embryo. Development 137: 3953-3963.

Louvet S, Aghion J, Santa-Maria A, Mangeat P, Maro B. 1996. Ezrin becomes restricted to outer cells following asymmetrical division in the preimplantation mouse embryo. Dev Biol 177: 568-579.

Ma GT, Roth ME, Groskopf JC, Tsai FY, Orkin SH, Grosveld F, Engel JD, Linzer DI. 1997. GATA-2 and GATA-3 regulate trophoblast-specific gene expression in vivo. Development 124: 907-914.

Maro B, Johnson MH, Pickering SJ, Louvard D. 1985. Changes in the distribution of membranous organelles during mouse early development. J Embryol Exp Morphol 90: 287-309.

McDole K, Xiong Y, Iglesias PA, Zheng Y. 2011. Lineage mapping the preimplantation mouse embryo by two-photon microscopy, new insights into the segregation of cell fates. Dev Biol 355: 239-249.

Meilhac SM, Adams RJ, Morris SA, Danckaert A, Le Garrec JF, ZernickaGoetz M. 2009. Active cell movements coupled to positional induction are involved in lineage segregation in the mouse blastocyst. Dev Biol 331: $210-221$.

Mesnard D, Filipe M, Belo JA, Zernicka-Goetz M. 2004. The anteriorposterior axis emerges respecting the morphology of the mouse embryo that changes and aligns with the uterus before gastrulation. Curr Biol 14: 184-196.

Messerschmidt DM, Kemler R. 2010. Nanog is required for primitive endoderm formation through a non-cell autonomous mechanism. Dev Biol 344: 129-137.

Mitsui K, Tokuzawa Y, Itoh H, Segawa K, Murakami M, Takahashi K, Maruyama M, Maeda M, Yamanaka S. 2003. The homeoprotein Nanog is required for maintenance of pluripotency in mouse epiblast and ES cells. Cell 113: 631-642.

Morris SA, Teo RT, Li H, Robson P, Glover DM, Zernicka-Goetz M. 2010. Origin and formation of the first two distinct cell types of the inner cell mass in the mouse embryo. Proc Natl Acad Sci 107: 6364-6369.

Morrisey EE, Tang Z, Sigrist K, Lu MM, Jiang F, Ip HS, Parmacek MS. 1998. GATA6 regulates HNF4 and is required for differentiation of visceral endoderm in the mouse embryo. Genes Dev 12: 3579-3590.

Murray P, Edgar D. 2001. Regulation of laminin and COUP-TF expression in extraembryonic endodermal cells. Mech Dev 101: 213-215.

Nakagawa M, Koyanagi M, Tanabe K, Takahashi K, Ichisaka T, Aoi T, Okita K, Mochiduki Y, Takizawa N, Yamanaka S. 2008. Generation of induced pluripotent stem cells without Myc from mouse and human fibroblasts. Nat Biotechnol 26: 101-106.

Niakan KK, Ji H, Maehr R, Vokes SA, Rodolfa KT, Sherwood RI, Yamaki M, Dimos JT, Chen AE, Melton DA, et al. 2010. Sox17 promotes differentiation in mouse embryonic stem cells by directly regulating extraembryonic gene expression and indirectly antagonizing self-renewal. Genes Dev 24: 312-326.

* Nichols J, Smith A. 2012. Pluripotency in the embryo and in culture. Cold Spring Harb Perspect Biol doi: 10.1101/cshperspect.a008128.

Nichols J, Zevnik B, Anastassiadis K, Niwa H, Klewe-Nebenius D, Chambers I, Scholer H, Smith A. 1998. Formation of pluripotent stem cells in the mammalian embryo depends on the POU transcription factor Oct4. Cell 95: 379-391.

Nichols J, Silva J, Roode M, Smith A. 2009. Suppression of Erk signalling promotes ground state pluripotency in the mouse embryo. Development 136: 3215-3222.

Nishioka N, Yamamoto S, Kiyonari H, Sato H, Sawada A, Ota M, Nakao K, Sasaki H. 2008. Tead4 is required for specification of trophectoderm in pre-implantation mouse embryos. Mech Dev 125: 270-283.

Nishioka N, Inoue K, Adachi K, Kiyonari H, Ota M, Ralston A, Yabuta N, Hirahara S, Stephenson RO, Ogonuki N, et al. 2009. The Hippo signaling pathway components Lats and Yap pattern Tead4 activity to distinguish mouse trophectoderm from inner cell mass. Dev Cell 16: $398-410$.
Nishiyama A, Xin L, Sharov AA, Thomas M, Mowrer G, Meyers E, Piao Y, Mehta S, Yee S, Nakatake YS, et al. 2009. Uncovering early response of gene regulatory networks in ESCs by systematic induction of transcription factors. Cell Stem Cell 5: 420-433.

Niwa H, Masui S, Chambers I, Smith AG, Miyazaki J. 2002. Phenotypic complementation establishes requirements for specific POU domain and generic transactivation function of Oct-3/4 in embryonic stem cells. Mol Cell Biol 22: 1526-1536.

Niwa H, Toyooka Y, Shimosato D, Strumpf D, Takahashi K, Yagi R, Rossant J. 2005. Interaction between Oct3/4 and Cdx2 determines trophectoderm differentiation. Cell 123: 917-929.

Niwa H, Ogawa K, Shimosato D, Adachi K. 2009. A parallel circuit of LIF signalling pathways maintains pluripotency of mouse ES cells. Nature 460: $118-122$.

Ohno S. 2001. Intercellular junctions and cellular polarity: The PARaPKC complex, a conserved core cassette playing fundamental roles in cell polarity. Curr Opin Cell Biol 13: 641-648.

Palmieri SL, Peter W, Hess H, Scholer HR. 1994. Oct-4 transcription factor is differentially expressed in the mouse embryo during establishment of the first two extraembryonic cell lineages involved in implantation. Dev Biol 166: 259-267.

Parfitt DE, Zernicka-Goetz M. 2010. Epigenetic modification affecting expression of cell polarity and cell fate genes to regulate lineage specification in the early mouse embryo. Mol Biol Cell 21: 2649-2660.

Pauken CM, Capco DG. 2000. The expression and stage-specific localization of protein kinase $\mathrm{C}$ isotypes during mouse preimplantation development. Dev Biol 223: 411-421.

Pedersen RA, Wu K, Balakier H. 1986. Origin of the inner cell mass in mouse embryos: Cell lineage analysis by microinjection. Dev Biol 117: 581-595.

Perea-Gomez A, Camus A, Moreau A, Grieve K, Moneron G, Dubois A, Cibert C, Collignon J. 2004. Initiation of gastrulation in the mouse embryo is preceded by an apparent shift in the orientation of the anterior-posterior axis. Curr Biol 14: 197-207.

Pfister S, Steiner KA, Tam PP. 2007. Gene expression pattern and progression of embryogenesis in the immediate post-implantation period of mouse development. Gene Expr Patterns 7: 558-573.

Piotrowska-Nitsche K, Perea-Gomez A, Haraguchi S, Zernicka-Goetz M. 2005. Four-cell stage mouse blastomeres have different developmental properties. Development 132: 479-490.

Plachta N, Bollenbach T, Pease S, Fraser SE, Pantazis P. 2011. Oct4 kinetics predict cell lineage patterning in the early mammalian embryo. Nat Cell Biol 13: 117-123.

Plusa B, Frankenberg S, Chalmers A, Hadjantonakis AK, Moore CA, Papalopulu N, Papaioannou VE, Glover DM, Zernicka-Goetz M. 2005. Downregulation of Par3 and aPKC function directs cells towards the ICM in the preimplantation mouse embryo. J Cell Sci 118: $505-515$.

Plusa B, Piliszek A, Frankenberg S, Artus J, Hadjantonakis AK. 2008. Distinct sequential cell behaviours direct primitive endoderm formation in the mouse blastocyst. Development 135: 3081-3091.

Pratt HP, Ziomek CA, Reeve WJ, Johnson MH. 1982. Compaction of the mouse embryo: An analysis of its components. J Embryol Exp Morphol 70: $113-132$.

Ralston A, Rossant J. 2008. Cdx2 acts downstream of cell polarization to cell-autonomously promote trophectoderm fate in the early mouse embryo. Dev Biol 313: 614-629.

Ralston A, Cox BJ, Nishioka N, Sasaki H, Chea E, Rugg-Gunn P, Guo G, Robson P, Draper JS, Rossant J. 2010. Gata3 regulates trophoblast development downstream of Tead 4 and in parallel to Cdx2. Development 137: 395-403.

Reeve WJ, Ziomek CA. 1981. Distribution of microvilli on dissociated blastomeres from mouse embryos: Evidence for surface polarization at compaction. J Embryol Exp Morphol 62: 339-350.

Rivera-Perez JA, Mager J, Magnuson T. 2003. Dynamic morphogenetic events characterize the mouse visceral endoderm. Dev Biol 261: 470487. 
Rodriguez TA, Srinivas S, Clements MP, Smith JC, Beddington RS. 2005. Induction and migration of the anterior visceral endoderm is regulated by the extra-embryonic ectoderm. Development 132: 2513-2520.

Rossant J, Tam PP. 2009. Blastocyst lineage formation, early embryonic asymmetries and axis patterning in the mouse. Development 136: $701-713$.

Russ AP, Wattler S, Colledge WH, Aparicio SA, Carlton MB, Pearce JJ, Barton SC, Surani MA, Ryan K, Nehls MC, et al. 2000. Eomesodermin is required for mouse trophoblast development and mesoderm formation. Nature 404: 95-99.

Shen MM. 2007. Nodal signaling: Developmental roles and regulation. Development 134: 1023-1034.

Shimoda M, Kanai-Azuma M, Hara K, Miyazaki S, Kanai Y, Monden M, Miyazaki J. 2007. Sox17 plays a substantial role in late-stage differentiation of the extraembryonic endoderm in vitro. J Cell Sci 120: 3859-3869.

Shimosato D, Shiki M, Niwa H. 2007. Extra-embryonic endoderm cells derived from ES cells induced by GATA factors acquire the character of XEN cells. BMC Dev Biol 7: 80.

Silva J, Nichols J, Theunissen TW, Guo G, van Oosten AL, Barrandon O, Wray J, Yamanaka S, Chambers I, Smith A. 2009. Nanog is the gateway to the pluripotent ground state. Cell 138: 722-737.

Sobel JS. 1983a. Cell-cell contact modulation of myosin organization in the early mouse embryo. Dev Biol 100: 207-213.

Sobel JS. 1983b. Localization of myosin in the preimplantation mouse embryo. Dev Biol 95: 227-231.

Soudais C, Bielinska M, Heikinheimo M, MacArthur CA, Narita N, Saffitz JE, Simon MC, Leiden JM, Wilson DB. 1995. Targeted mutagenesis of the transcription factor GATA-4 gene in mouse embryonic stem cells disrupts visceral endoderm differentiation in vitro. Development 121: 3877-3888.

Srinivas S, Rodriguez T, Clements M, Smith JC, Beddington RS. 2004. Active cell migration drives the unilateral movements of the anterior visceral endoderm. Development 131: 1157-1164.

Stephens LE, Sutherland AE, Klimanskaya IV, Andrieux A, Meneses J, Pedersen RA, Damsky CH. 1995. Deletion of $\beta 1$ integrins in mice results in inner cell mass failure and peri-implantation lethality. Genes Dev 9: 1883-1895.

Stephenson RO, Yamanaka Y, Rossant J. 2010. Disorganized epithelial polarity and excess trophectoderm cell fate in preimplantation embryos lacking E-cadherin. Development 137: 3383-3391.

Strumpf D, Mao CA, Yamanaka Y, Ralston A, Chawengsaksophak K, Beck F, Rossant J. 2005. Cdx2 is required for correct cell fate specification and differentiation of trophectoderm in the mouse blastocyst. Development 132: 2093-2102.

Surani MA, Handyside AH. 1983. Reassortment of cells according to position in mouse morulae. J Exp Zool 225: 505-511.

Suwinska A, Czolowska R, Ozdzenski W, Tarkowski AK. 2008. Blastomeres of the mouse embryo lose totipotency after the fifth cleavage division: Expression of Cdx2 and Oct 4 and developmental potential of inner and outer blastomeres of 16- and 32-cell embryos. Dev Biol 322: $133-144$

Takaoka K, Hamada H. 2012. Cell fate decisions and axis determination in the early mouse embryo. Development 139: 3-14.

Takaoka K, Yamamoto M, Shiratori H, Meno C, Rossant J, Saijoh Y, Hamada H. 2006. The mouse embryo autonomously acquires anterior-posterior polarity at implantation. Dev Cell 10: 451-459.

Takaoka K, Yamamoto M, Hamada H. 2011. Origin and role of distal visceral endoderm, a group of cells that determines anterior-posterior polarity of the mouse embryo. Nat Cell Biol 13: 743-752.
Tam PP. 2004. Embryonic axes: The long and short of it in the mouse. Curr Biol 14: R239-241.

Tam PP, Loebel DA. 2007. Gene function in mouse embryogenesis: Get set for gastrulation. Nat Rev Genet 8: 368-381.

Tam PP, Gad JM, Kinder SJ, Tsang TE, Behringer RR. 2001. Morphogenetic tissue movement and the establishment of body plan during development from blastocyst to gastrula in the mouse. Bioessays 23: 508-517.

Tam PP, Loebel DA, Tanaka SS. 2006. Building the mouse gastrula: Signals, asymmetry and lineages. Curr Opin Genet Dev 16: 419-425.

Tarkowski AK, Wroblewska J. 1967. Development of blastomeres of mouse eggs isolated at the 4- and 8-cell stage. J Embryol Exp Morphol 18: $155-180$.

Tarkowski AK, Suwinska A, Czolowska R, Ozdzenski W. 2010. Individual blastomeres of 16- and 32-cell mouse embryos are able to develop into foetuses and mice. Dev Biol 348: 190-198.

Thomas FC, Sheth B, Eckert JJ, Bazzoni G, Dejana E, Fleming TP. 2004. Contribution of JAM-1 to epithelial differentiation and tight-junction biogenesis in the mouse preimplantation embryo. J Cell Sci 117: $5599-5608$

Torres-Padilla ME, Parfitt DE, Kouzarides T, Zernicka-Goetz M. 2007a. Histone arginine methylation regulates pluripotency in the early mouse embryo. Nature 445: 214-218.

Torres-Padilla ME, Richardson L, Kolasinska P, Meilhac SM, LuetkeEversloh MV, Zernicka-Goetz M. 2007b. The anterior visceral endoderm of the mouse embryo is established from both preimplantation precursor cells and by de novo gene expression after implantation. Dev Biol 309: 97-112.

Wada K, Itoga K, Okano T, Yonemura S, Sasaki H. 2011. Hippo pathway regulation by cell morphology and stress fibers. Development 138: $3907-3914$

Wang AZ, Ojakian GK, Nelson WJ. 1990. Steps in the morphogenesis of a polarized epithelium. I. Uncoupling the roles of cell-cell and cellsubstratum contact in establishing plasma membrane polarity in multicellular epithelial (MDCK) cysts. J Cell Sci 95: 137-151.

Weber RJ, Pedersen RA, Wianny F, Evans MJ, Zernicka-Goetz M. 1999. Polarity of the mouse embryo is anticipated before implantation. Development 126: 5591-5598.

Wu G, Gentile L, Fuchikami T, Sutter J, Psathaki K, Esteves TC, ArauzoBravo MJ, Ortmeier C, Verberk G, Abe K, et al. 2010. Initiation of trophectoderm lineage specification in mouse embryos is independent of Cdx2. Development 137: 4159-4169.

Yagi R, Kohn MJ, Karavanova I, Kaneko KJ, Vullhorst D, Depamphilis ML, Buonanno A. 2007. Transcription factor TEAD4 specifies the trophectoderm lineage at the beginning of mammalian development. Development 134: 3827-3836.

Yamamoto M, Beppu H, Takaoka K, Meno C, Li E, Miyazono K, Hamada H. 2009. Antagonism between Smad1 and Smad2 signaling determines the site of distal visceral endoderm formation in the mouse embryo. J Cell Biol 184: 323-334.

Yamanaka Y, Lanner F, Rossant J. 2010. FGF signal-dependent segregation of primitive endoderm and epiblast in the mouse blastocyst. Development 137: 715-724.

Yang DH, Smith ER, Roland IH, Sheng Z, He J, Martin WD, Hamilton TC, Lambeth JD, Xu XX. 2002. Disabled-2 is essential for endodermal cell positioning and structure formation during mouse embryogenesis. Dev Biol 251: 27-44.

Ziomek CA, Johnson MH. 1980. Cell surface interaction induces polarization of mouse 8-cell blastomeres at compaction. Cell 21: 935-942.

Ziomek CA, Johnson MH. 1982. The roles of phenotype and position in guiding the fate of 16-cell mouse blastomeres. Dev Biol 91: 440-447. 


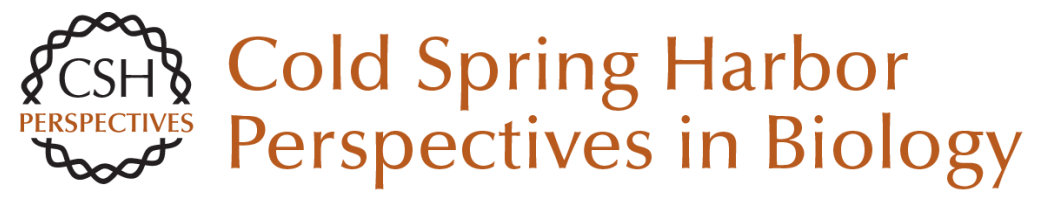

\section{Intercellular Interactions, Position, and Polarity in Establishing Blastocyst Cell Lineages and Embryonic Axes}

Robert O. Stephenson, Janet Rossant and Patrick P.L. Tam

Cold Spring Harb Perspect Biol 2012; doi: 10.1101/cshperspect.a008235

Subject Collection Mammalian Development

The Dynamics of Morphogenesis in the Early

Mouse Embryo

Jaime A. Rivera-Pérez and Anna-Katerina

Hadjantonakis

microRNAs as Developmental Regulators Kathryn N. Ivey and Deepak Srivastava

Development of the Endochondral Skeleton Fanxin Long and David M. Ornitz

Adipogenesis

Kelesha Sarjeant and Jacqueline M. Stephens

Molecular Mechanisms of Inner Ear Development

Doris K. Wu and Matthew W. Kelley

Polarity in Mammalian Epithelial Morphogenesis Julie Roignot, Xiao Peng and Keith Mostov

Eye Development and Retinogenesis Whitney Heavner and Larysa Pevny

Primordial Germ Cells in Mice

Mitinori Saitou and Masashi Yamaji

Cell Division Modes and Cleavage Planes of

Neural Progenitors during Mammalian Cortical

Development

Fumio Matsuzaki and Atsunori Shitamukai

Blood and Lymphatic Vessel Formation

Victoria L. Bautch and Kathleen M. Caron

Transcriptional Networks in Liver and Intestinal

Development

Karyn L. Sheaffer and Klaus H. Kaestner

Pluripotency in the Embryo and in Culture Jennifer Nichols and Austin Smith

Signaling and Transcriptional Networks in Heart

Development and Regeneration

Benoit G. Bruneau

Signals and Switches in Mammalian Neural Crest

Cell Differentiation

Shachi Bhatt, Raul Diaz and Paul A. Trainor

Hematopoiesis

Michael A. Rieger and Timm Schroeder

Intercellular Interactions, Position, and Polarity in

Establishing Blastocyst Cell Lineages and

Embryonic Axes

Robert O. Stephenson, Janet Rossant and Patrick

P.L. Tam

For additional articles in this collection, see http://cshperspectives.cshlp.org/cgi/collection/

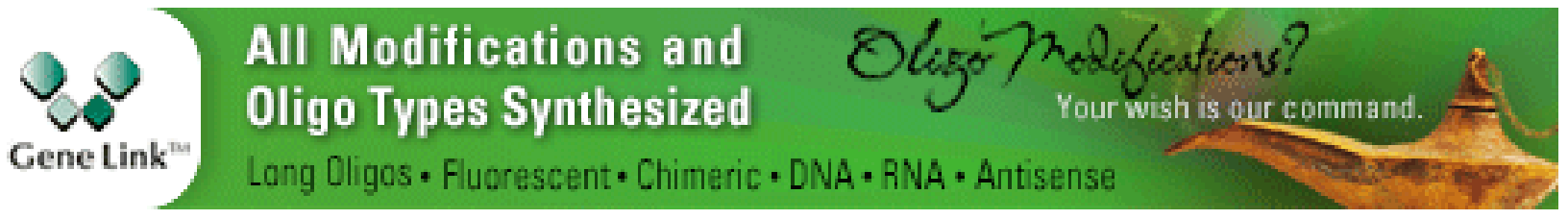

Copyright @ 2012 Cold Spring Harbor Laboratory Press; all rights reserved 
For additional articles in this collection, see http://cshperspectives.cshlp.org/cgi/collection/

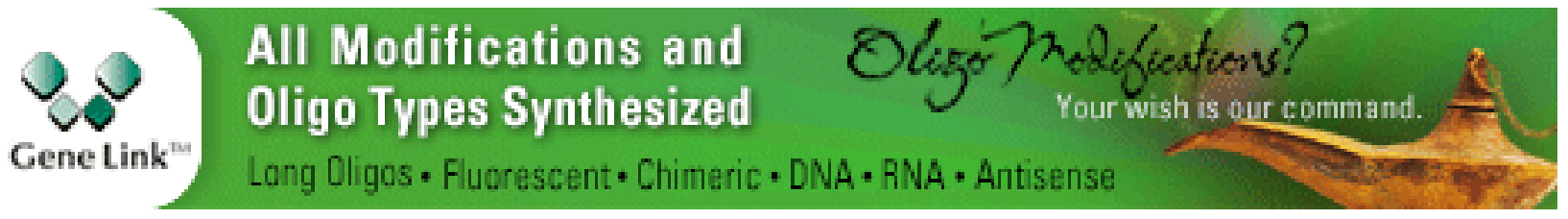

Copyright @ 2012 Cold Spring Harbor Laboratory Press; all rights reserved 